\author{
ALLA MAKAROVA, \\ Zhytomyr State University (Zhytomyr, Ukraine) \\ e-mail: Makarova_AO@ukr.net, ORCID 0000-0001-7270-0135
}

\title{
ARCHETYPICAL APPROACH TO ACTIVITY: LEGITIMATION BY PRACTICE
}

Modern reality needs to be put into practice, asserted as a program of practical activity by newly developed theoretically approaches, among which the archetypal approach seems to be one of the most promising, since it takes into account the real motives of the actors as subjects. The features of the archetypal approach to activities in certain spheres of social practice from the point of view of realization in everyday life, and not only in theory, are highlighted in the article. Thus, examples of the application of the archetypal approach in marketing practice, in particular branding, in pedagogical practice and in the practice of political diplomacy, are considered. The importance of taking into account the archetypal tendency of the objects of influence in these spheres and the construction of an adequate scheme of activity, including on these principles, is emphasized. An extensive list of individual archetypal classifications is given, archetypes and roles differentiated. The model of the twelve archetypes of M. Mark and KS Pearson was used as a methodological base, among which the types "Simple", "Glorious Small", "Careful", "Creator", "Sage", "Seeker", "Rebel", "Clown", "Hero", "Mage", "Ruler". The difference between the content of the outlook of these archetypes is exemplified by their actual or potential legitimation in the practice of branding, pedagogy and diplomacy. The author uses Ukrainian realities, in particular, conducts an archetypal analysis of diplomatic negotiations between the leadership of Russia and the heads of European states over the end of the war in eastern Ukraine. We propose our own assessment of the reasons for the ineffectiveness of such negotiations in terms of archetypal approach. An overview of the achievements of modern Ukrainian scientists in the direction of legitimizing the archetypal approach in different spheres of practice is given.

Keywords: archetype; archetypal approach; activity; branding; role; pedagogy; diplomacy.

\section{Introduction}

The ultimate goal of science is to prove the scientific theory by practice. The theoretical models and approaches elaborated by science should be proved by practice of being legitimize as appropriate and useful for the real people in different spheres of their activity. An archetypal approach is one of the promising in the light of practice legitimation. For instance, it has been efficiently used in branding through exploiting a model of twelve archetypes for customer profile identification with the aim of designing the advertising products clearly focused on target audience. We consider that the spheres of pedagogy, diplomacy also need a clear practice approach to their realization in order to react adequately to the specific problems and create a concise algorithm how to act in the ambiguous situations and achieve an aspirational goal. Unfortunately, there are moments that complicate and limit such legitimization and implementation within the scientific theories, in particular archetypal approach, for instance the discussion related to the terminological and classification moments. Consequently, the practice of pedagogical and diplomatic activity has not taken into account the archetypal inclination of the subjects or clearly aimed at their real motivation. It is vital to design a clear scheme for the social scenarios' explanation with regard to the archetypal approach along with the popular and legitimized biological and social approaches. Practical implementation of some philosophical theories, particularly voluntarism, atheism, ni- hilism, often results in anti-humanistic and contra- humanistic consequences. In our view, the theory of archetypes does not belong to the range of methodological bases dangerous for the social stability, as the archetypes possess a representational potential of the human activity universal senses and do not have a direct correlation with historical and cultural markers. On the contrary, the active application to the archetypes' analysis within various types of practical activity and achieving the planned and desired result is the best argument for the validity of archetypal activity determination.

There are more than enough scientific works devoted to the cross-disciplinary and cross-paradigmatic potentials of the archetypal approach in modern Ukrainian science. As Ukrainian and Russian researcher A. Nekita rightly noted in his thesis "Mechanisms of Unconscious Social Distortion of Archetypal Phenomenology" presented in 2001: "A research on the complex of various human connections with society in general as well as with the social institutes should base regarding to the specific character of formation and function of the social processes with the unconscious archetypal senses at individual, group and global levels. In another case, a scientist risks to disregard the a priori unconscious mechanisms without study which any effective social management is impossible" (Nekita, 2001: 6). The thought is legitimized by Ukrainian scientific cooperation in the sphere of archetypal approach. Thus, the Ukrainian School of Archetypes has provided intensive 
practical activity and with the National Academy of State Administration of the President of Ukraine organized contests, master classes, conferences, workshops, published collections of the scientific papers since 2010 . For instance, it was cooperation according to the theme of interconnection between archetypes and public administration within the context of civil processes of selforganization, social mobility and social integration in 2015 (Archetype and Public Administrations, 2015). The first theoretical and methodological seminar on "Archetypes and Public Administrations" with international participants took place in Ukrainian town Feodosia on July $13^{\text {th }}-14^{\text {th }}$ 2010. "The scientific forum innovational due to its character and content united cross-discipline attempts of more than 70 scientists and researchers from 10 European countries (Belorussia, France, Germany, Great Britain, Italy, Kazakhstan, Poland, Russia, Serbia, Ukraine) that worked in different spheres of social and humanitarian knowledge" (Public management, 2010: 5). The works of E. Afonin (Afonin \& Martynov, 2013), O. Donchenko, Y. Romanenko (2001), O. Radchenko (2014), O. Sushyy (2013) create a solid knowledge base for the scientific approaches of Ukrainian scientists to an archetypal concept. The scientific community performs theoretical as well as empirical analysis of the social life in the light of archetypal approach. For instance, "the Ukrainian School of Archetypes performed 84 monitoring studies (Sochan, 2019)" according to the authors' methods during 1992-2018-s. Expressing solidarity with their efforts we absolutely agree with the thought of $\mathrm{N}$. Kovtun regarding the necessity of practical legitimization of an archetypal approach to activity: "Under the circumstances of transition from traditional and archaic society to the modern one, irreversible destruction of monolithic human existence has occurred. The process is accompanied by splitting of the single existence phenomenon into different spheres from material to ideal. A place where the worldview organic formation has been torn or eliminated, in particular mythological worldview, the fertile ground for the experiments under a person and society in general appears. If a base of any value system is undermined then "true" knowledge will be torn into pieces, the unity will be lost or completely excluded from a spiritual tradition and mass consciousness manipulations will be possible" (Kovtun, 2009).

Regarding this, the urgent need is in the studies of a perfect human archetype as a phenomenon of social consciousness offered by V. Zakrevsky (2002), collective unconscious as a depth of ethnical mentality determination provided by Yu. Medynska (2004), the symbolic structures of ethnical process in Ukraine performed by N. Kovalchuk (2007). An analysis of archetypal bases of trust manipulation in communication practice suggested by $\mathrm{O}$. Kozhemyakina (2012) belongs to the modern Ukrainian studies as well as subject matter practical studies provided by M. Severynova (2012) and on its base the more general study of an archetype, concept and mythologeme in the systems of musical theories designed by Ch. Kazymiryv (2013), the studies of archetypes usage in the communicative practice provided by M. Butyrina (2013), an analysis of the primary guidelines of the comparative studies of archetypal characters offered by O.Nikolova (2014), an archetype as an esthetic dominant of the artistic expression of national identity dimension in Ukrainian poetry performed by T.Urys (2016), a study of mythological poetics as a way of Ukrainian identity modelling proposed by $\mathrm{R}$. Demchuk (2018).
The aim of the paper is to illustrate the legitimized urgency of an archetypal approach in the practical spheres of human relations, namely in the practice of branding, pedagogy and diplomacy; identification and clarification of legitimized effect according to an archetypal tendency of objects of influence in the presented spheres.

\section{Methods}

The article is based on the methods of critical analysis and synthesis, comparison, analogy and theoretical illustration by practice, typological method. The study is built on the principles of scientific development, objectivity, cognitivism, systemic integration, contextual interpretation, multiplicity of worldviews. The archetypal model of twelve archetypes offered in the book "The Hero and the Outlaw: Building Extraordinary Brands through the Power of Archetypes" written by Carol S. Pearson, the President of the CASA (Center of Archetypal Studies and Applications) and Margaret Mark who headed a consulting firm from brand design "Margaret Mark Strategic Insight" (Pearson \& Mark, 2005) was used as a common methodological base in the interpretation of Ukrainian authors A. Polykanova (2012), L. Belechova (2015) and Russian authors M. Arpentyeva and M. Braitseva (2018). The evaluation of insufficient archetypal practice in the pedagogical activity was performed by the means of literary illustration and abstraction of the particular reality.

\section{Research and Results}

Nevertheless, it is hard to understand how to apply knowledge of the archetypes' existence in the collective unconscious in practice due to the diversity of research directions and theoretical approaches. Particularly, the basic difficulties occur with the classification. For instance, we analyze a part from the bibliographically significant work (that contains 58 literature sources and additional illustrative material) by L. Belechova "Archetype, Archetypal sense, Archetypal Image in the Linguistic and Cognitive Depiction..." (Belekhova, 2015) where the author draws a common distinction between psychological and cultural archetypes. We save the authors' references to the literature, and take them as a quotation in full in order to illustrate the degree of ambiguity even with the references to the sources and coordination of classifications.

"Having systematized C. Jung's views and the views of other scientists on the nature of an archetype in general, we identified a number of archetypes among which were the psychological archetypes explained as a display of the collective unconscious and cultural archetypes such as a code of common humanity culture. The archetypes: Self, His, Shadow, Spirit, Anima, Animus, Mother/Woman, Light, Darkness, Fire, Water, Earth, Air, See, Orientation, Regeneration or Transformation can be referred to the psychological ones [33-a, 93-95, 109, 112, 123, 124, 126, 139, 145-148; 34, 422;17, 108, 169; 23, 577]... The archetypes: Trinity, Madonna or Mother of God, Person/ Mask, Hero/Trickster, Eternal Traveler, World Tree, World Egg, Wise Man/Woman, Life, Death, Development, Metamorphosis, namely Transformation, etc. are referred to the cultural ones [17, 108,169; 28, 111-115; 10]" (Belekhova, 2015: 9).

The list immediately evokes a number of questions, particularly, what are the practical correlations between the archetypes-phenomena, archetypes-things and archetypes-persons (including their unification under one discourse such as a World Egg, Development and Hero, in 
order to obtain not a fiction but science; why a Woman is an psychological archetype, whereas an Old Woman is a cultural one and what is derived from what; what are the differences of Transformation as psychological and cultural archetypes, etc.). Such crucial and interesting issues create a phenomenon that is like to the situation when "you cannot see the forest for the trees" and leave the scientists in the scope of entire theory.

Consequently, the determination influence of an archetype on the activity is clearly described in the texts and studies devoted to the practical aspects of the activity spheres where instrumentality, scheme and plan of the actions are the determined characteristics of their success, for instance in marketing. They immediately direct a practitioner at the content's system of some archetypes without any claims for methodological and terminological analysis in a way of their usage during the work with the particular persons or groups, for instance consumers or patients. The market researchers determine the list of archetypes as well as decipher their psychological and mental sense, offer their practice usage, particularly branding without dwelling on the differentiation difficulties in an archetype and archetypal image, symbol and pattern, gestalt and habitus. Based on the schemes proposed by C. S. Pearson and M. Mark, they create the colored diagrams of twelve archetypes that are sufficient for the identification of a basic model of consumer's behavior according to them. There are the following archetypes among them: "A Ruler (ES) is authoritative, possesses a status, prestige, and performs the role of control and facilitation. A Hero (ET) is professional, winning, entrepreneurial, rich and successful. A Wise Man (IT) is intellectual, objective, logical, someone who knows life, wise. An Adventurer (IN) is someone who seeks unique, and is individual, free, someone who realizes the projects, reveals the mysteries, obtains self-knowledge and learns the world. A Child (EN) is someone who enjoys life, is cheerful, careless, someone who discovers the new possibilities and loves the world. A Lover (EF) is someone who is handsome, sexual, passionate, and sensitive, someone who aims at community, communication, intimacy. A Nice Guy (IF) is kind, sincere, loyal, moral, friendly, honest. A Guard (IS) is comfortable, easy-going, calm, someone who enjoys, renews his strength, careful" (Arpentyeva \& Braiceva, 2018). A.Polikanova defines and characterizes the archetypes of Mage, Clown (Trickster), Creator, Rebel in table form. Particularly, she gives a number of mottos of the defined archetypes' representatives that they use in their life (Polikanova, 2012).

Such practical directness embarrasses a serious researcher who expects "the pitfalls". (The Internet sites confuse even more when an automatic system defines your archetype with a short characteristic and anime after having posed 100 questions online). Despite the practical convenience of an instrumental approach, an issue of hierarchy of archetypes (chaotic "horizontal" position of such archetypes as a Wise Man, Creator, Ruler, Clown makes a wish to distribute the knowledge according to a vertical system) is still opened. About the common and difference (particularly accuracy) in psychological characteristics (the existence of such features in the archetypes "Simple-hearted/Child", "Nice Guy" and "Careful", and also "Rebel", "Adventurer", "Hero" leads to a question about their generalized original source, image), mottos' accuracy, particularly, the motto "power is not all", cannot be associated with the archetype of a Ruler, exactly the opposite motto "divide and rule" suits better, and its sense that "a thing is a sign of power" belongs to an archetype of an Owner; a motto "it can happen" does not directly indicate an archetype of a Mage, alternatively, a motto "The miracles are made by hands!" (O. Grin "Scarlet Sails") suits better. The exclusive figuration and personality of the offered archetypes reduce the determination influence of an archetype to a situation (when a consumer imagines himself as a Wise Man, Adventurer, Ruler, Clown, however, he is not himself, in a situation when the other archetypal parameters of performance are absent, such as substantial, procedural parameters, factor aspects of the archetypal matrix), etc. Consequently, the specialists from branding sphere say directly that "if you know an archetype of your consumer you should not know anything more" (Los, 2019), in other words a problem field of the archetypal determination diversity is consciously limited. Marketing as a part of economic activity is the specific attitude to a person and the leading roles focused on the field are a "Producer" and a "Customer" (the first one is a source of a good and the second one is a seeker of a good). The abovementioned archetypes have lost their volume, selfvalue, and are considered only as an addition to the main roles.

The same generalized and specified roles' structuring is typical for all other fields of social activity. For instance, the central roles in medicine will be performed by a "Doctor" and a "Patient" (as a source of health and its seeker); the central roles in pedagogical activity will be performed by a "Teacher" and a "Learner" (as a source and successor of decent behavior); in religious system the main roles will belong to a "Priest" and a "Sinner" (as a source of holy and a seeker of it); in legal area the main roles will be distributed to a "Legal Norms' Beholder" and an "Offender", etc. Nevertheless, a distinction between an archetype and a role is one of the crucial factors of determination for the activity in general. Having involved into the various social fields simultaneously, a person saved his internal identity, personal habitus despite the performed role as an archetype under the various demands to the same model of behavior based on the following parameters of time, space, energy, communication, moral, value (Kovtun, 2009). Indeed, a person is a Wise Man or Clown, Ruler or Careful Person, Creator or Rebel regardless of his role and his social scenario that is being performed at the moment whether he is included into a system of political or art, military or household, recreational or penitentiary institutions and what of two basic roles are being performed at the moment. The roles' changing is typical for a system of social and humanitarian activity not only due to the mechanical social mobility; it is often realized as "a play of forces" in practice. Romankova L. noted the peculiarity of a game interaction as a particular "competition" in the context of high school management (the bold type is authorial A.M.): "The educational interaction in high school space is created, recreated and formed on the base of two algorithms: 1) the social education mechanics, the leading role belongs to a teacher (it is regarding a role - A.M.) and 2 ) self-education mechanism, the leading role is performed by a person (it is regarding an object of practical influence - A.M.), a future specialist. They seemingly argue and play with each other, delivering an actual character to the educational contacts with the constant change of a leader (it is regarding an archetype - A.M.)" (Romankova, 2015: 199).

A correlation between Trickster's (Shadow's) archetype 
and one of the enumerated archetypal models, for instance a Clown, raises doubts. In our view, being a dark aspect of a person, Trickster is realized in some figures or is an integral active sense of the whole archetypal and value complexes, and as at most, is a reversed side of possible enumerated and not enumerated archetypal figures presented in the classification (Tychovska, 2015: 132). With no possibility to dwell on the question and due to the context of the study, we need to stress that being an antagonist of a Person; Trickster creates the most pedagogical problems according to his psychological and archetypal characteristics. Idealizing a Person's archetype, pedagogy distances from Trickster's existence in every possible way, nevertheless it has to deal with him in practice. Furthermore, the methodological usage of motives and deeds' analysis and the methods of their consequences' correction could permit to align pedagogical view on the subjects of education influence with the objective practice. The views are occasionally so much idealistic that totally ignore a possibility and real existence of the deviant models of pupils' behavior in the sense of delinquent behavior. The vast majority of declarations and pedagogical programs have priority in an abstract objective of "personal development", as the program can collide with the necessity not to develop, but prevent delinquent activity or correct it. A problem statement of "personal development" without taking into account the actual personal tendencies and potentials is doomed to defeat as it has no common spheres of influence with a real object. The drawbacks are partially corrected in the concepts of individual oriented and professional oriented (specialized) education. Nevertheless, the task of the program qualitative realization in a class of not less than 30 boarders (not pupils) at the secondary level is unreal for a particular educator. The programs of pedagogical correction for a person with the archetypal identities of a Wise Man and Clown should be different and have the tasks for the intrinsic personal nature development as well as the assignments for the situational compensation of archetypal deficit of qualities, at the minimum Clown's refocusing on constructive activity and at the maximum the application to the practical disappearance of Dunno's qualities of a potential Wise Man. The conception of conscious necessity as freedom (due to the principle of verification of equation veracity by parts' rearrangement) applied to the pedagogical activity is no longer tenable, as the awareness of action necessity does not exempt from unwillingness to act. In other words the main problem regards the unwillingness of a Wise Man to be a Clown and vice-versa. Everyone will avoid non typical situation for their subliminal activity even endeavor "being himself in the other position". The conflict situations of different types such as Trickster collision with the system offered by a figure of Person type are often described in fiction literature by the means of comedy or satire (for instance, the guys' images from Mark Twain's novel "Tom Sawyer and Huckleberry Finn" and Albert page in a novel by Pelham Grenville Wodehouse "The Girl in Blue") as well as they are depicted by the colors of social optimism as a long and thorny path of Dunno's socialization in the novels of Mykola Nosov. Nevertheless, there is serious and pedagogical literature, for instance "The Pedagogical Poem" by Anton Makarenko where the tough work of an educator is described who has to be flexible and creative, be able to make compromise with conscience, use the strongest available methods and even brutal ones for influence on the boar- ders. It was stated that not all efforts were fruitful, moreover, the successful efforts were the only ones directed at the persons who were inclined to humanitarian openness (sensitivity). A Pupil as an object of pedagogical influence or material for pedagogical work, has (a right or responsibility) to present any kind of archetype, a Teacher as a subject of influence does not have such right. Being adequate to a boarder's personality, the methods of pedagogical influence should have an ad hoc basis; nevertheless an aspiration for his fate improving, true love for a child should be permanent. We are pleased with the emergence of the monographs where such approach scientifically explained and interpreted, for instance the work presented by O. Donchenko "Archetypal Management" (Donchenko, 2012) and A. Kravchenko's work "Archetype of a Teacher: Idea, Image, Responsibility: Monography" (Kravchenko, 2013). Obviously, the pragmatic, subjective or selfish motives, childishness or aggressiveness should be contraindications to pedagogical practice for their holders. Still, they will not prevent a banker, artist, woodcarver or gardener from performing his professional activity.

A sphere of political (and domestic) diplomacy is equally convincing as branding and pedagogy in the sense of an archetypal theory application. A failure in an example, image, ideal, motive selection can negate all process of persuading (negotiation), even when there are no physical actions applied and the whole influence has purely psychological and emotional character. The history of the recent negotiations between the heads of European countries and modern Russian authorities, aimed at the military conflict regulation in modern Ukraine, proves that the endeavors of convincing cede power, wealth and cease to perform hooliganism due to any format "Council of the Wise/Careful/Nice Guys" (according to E. Berne - Adults (Berne, 2016), according to C. Jung - Persons (Yung, 1996)) are not just fruitless and ridiculous, they are tragic waste of time on a person with the psychological and archetypal complex of a "Ruler/Clown/Rebel" (according to E. Fromm - Child, according to C. Jung - Trickster). They are based on a system of values that is absolutely alien and incomprehensible for a Trickster, furthermore, any liberal or humanistic format will not bring such results that are given by the united radical resistance of the Ukrainian military forces in the model of archie matrix "Rebel/Hero/ Mag" and Ukrainian volunteers in the model of archie matrix "Careful/Creator/Adventurer". Everything that is expressed at domestic level as sympathy or antipathy will be rationally proved and presented according to the coordinates "acceptable" or "unacceptable" in diplomatic language. This is, however, permission, sanction to perform further actions on the base of acceptance or objection the offered value and moral orientations; consequently it is about acceptance in a form of interiorization, integration, assimilation or about objection, denial in a form of confrontation, conflict, disintegration. Namely, the question of cooperation or conflict as the social processes that can be realized in the relations "Ukraine - Russia" should not be considered just in the light of situational behavior interactions, but as constantly repeated archetypal collective subliminal scenarios which are fractal and fatal, where Russia inevitably brings assimilation and disintegration into Ukraine under the pretext of integration and internationalization, has implemented "shadows' play" as well as the scenario of re-version and inversion (in logical and physical understanding). It was crucial to realize that 
Russian "messianic" position based on an archetype of "a mother that was presented in a mythological form of "Holy Rus" in Russian Orthodox consciousness and was purified as a messianic concept "Moscow is the third Rome" with a theurgic character of social and individual practice oriented on personal deification and collective transformation" (Dubnichenko, 2005: 5). Although, except strategical activity that is performed a role of theory, the tactic plays the vital role that according to the practical realization of "art of small steps" corrects the drawbacks of a strategy if they are found. Obviously, that what is acceptable as a strategy of internationalization for the modern Ukrainian education or a strategy of diversification for the modern Russian economy cannot be accepted uncritically and be extrapolated in the direct proportion to an active political strategy of Russia and Ukraine modern relations. The best credentials for retaining Ukrainian independence are prevalence of the processes of divergence over the processes of convergence in such relations.

The correct understanding of the difference between the spheres of activity and institutional and organizational environment regarding the processes that have the same titles, but the different content is crucially important for the right tactical action that serve the interests of the particular social institutes and organizations. The last two can be identified only via their value and archetypal bases differentiation, for instance, education and economy, penitentiary and social spheres, art and mass production, etc. Consequently, the emergence of the organizations focused on the connection of management theories (including public management) with the theory of archetypes and specialists that consider such theoretic work as the ground for constructive humanistic and humanitarian practice in a structure of Ukrainian scientific reality is vital.

\section{Conclusions}

The archetypal approach is one of the theoretically developed; nevertheless it is not enough for the scientific discoveries implementation and legitimization by practice. Furthermore, it should be more clearly fixed as a method of identification and simulation of the social processes in such practical spheres as pedagogy and diplomacy, similar to its usage in branding. The role models of a Wise Man and Rebel relevant for pedagogy or the models of a Rule and Simple-hearted relevant for diplomacy create the scenarios of interaction where a contradiction of worldviews as well as situational acts can be followed. The main thesis of an archetypal approach that reveals the possibilities to its legitimization by practice, namely the practical validity, is the acceptance of the fact that the archetypal inclination of a subject remains its basic characteristic despite a situational role in a social scenario. It permits to deviate from the official structural and role models of activity and focus on their internal psychological content. Despite all urgent remarks from the theory to the proportion and actual content of the archetypes, the theory itself has been constantly improved and aimed at the moment of boarder legitimation in practice. Consideration of its physiological and value bases in the practical activity permits to identify the complexes of its internal motivation and correct the systems of the external role relations. Managerial actions' implementation, including plans, schemes and models preparation based on the methodological grounds of an archetypal approach is the same loss as planning with the orientation on the voluntarybiologic theory that considers only status or economic determinants.

\section{REFERENCES}

Afonin, E. \& Martynov, A. (2013). Archetype and social: interaction and mutual influences. Public administration: theory and practice. Special Issue: 193-200. (In Ukrainian)

Afonin, E. A. (ed.), Ryabtsev, G. L. (ed.) (2015). Arkhetypika i derzhavne upravlinnya: hromadyanska samoorhanizatsiya, sotsialna mobilnist, suspilna intehratsya. Kyiv: Psycheya, 84 p. (In Ukrainian)

Arpentyeva, M. R. \& Braitseva, S. V. (2018). Archetypes and role models in visual branding. Znak: problemnoye pole mediaobrazovaniya, 2 (28). Retrieved from https://cyberleninka.ru/article/ n/arhetipy-i-rolevye-modeli-v-vizualnom-branding (In Russian)

Belekhova, L. I. (2015). Arkhetyp, arkhetypnyy smysl, arkhetypnyy obraz u linhvokohnityvnomu vysvitlenni (na materiali virshovanykh tekstiv amerykanskoyi poeziyi). Bulletin of the Drohobych Ivan Franko State Pedagogical University. Ser.: Philological Sciences (Linguistics). 3: 6-16. (In Ukrainian)

Berne, E. (2016). Igry, v kotoryye igrayut lyudi [Games that people play]. Nyköping (Sweden): Philosophical Archives, $164 \mathrm{p}$. (In Russian)

Butyrina, M. V. (2013). Do pytannya zastosuvannya arkhetypiv u komunikatsiyniy praktytsi. Bulletin of Dnipropetrovsk University. Social Communications Series, 13: 13-17 (In Ukrainian).

Demchuk, R. V. (2018). Mythopoetics as a Means of Modeling Ukrainian Identity: A Cultural-Civilizational Context (Candidat's thesis, Absrtact). Tchaikovsky National Music Academy. Kyiv, 34 p. (In Ukrainian)

Donchenko, O. A. (2012). Arkhetypovyy menedzhment. Kirovograd: Imex-LTD, 264 p. (In Ukrainian)

Donchenko, Olena and Romanenko, Yuriy (2001). Arkhetypy sotsialnoho zhyttya i polityka (Hlybynni rehulyatyvy psykhopolitychnoho povsyakdennya). Kyiv: Libid, 334 p. (In Ukrainian)

Dubnichenko, V. J. (2005). Specific character of Orthodox archetype reflection in Russian metaphysic tradition. (Candidat's thesis, Absrtact). Donetsk National University, 20 p. (In Ukrainian)

Kazimiriv, H. (2013). Arkhetyp, kontsept i mifolohema v systemi muzychnykh katehoriy. Bulletin of the Carpathian University: Art Studies. 28-29, part 1. Ivano-Frankivsk: 190-195. (In Ukrainian)

Kovalchuk, N. D. (2007). Symbolic Structures of the Ethnocultural Process in Ukraine (Doctor's thesis). Skovoroda Institute of Philosophy of NAS Ukraine, 404 p. (In Ukrainian)

Kovtun, N. M. (2009). Arkhetyp yak invariantna forma dukhovnoho zhyttya. Materials of the Scientific and Methodological Seminar. Retrieved from http://eprints.zu.edu.ua/6256/1/\%D0\%9A\%D0\%BE\%D0\%B2\%D1\%82\%D1\%83\%D0\%BD\%20\%D0\%9D \% 20\%D 0\%B 0\%D 1 \% 80\%D 1\% 85\%D0\%B \% D 1 \% 82\%D0\%B8\%D0\%BF\%20\%D1\%96\%D0\%BD\%D0\%B2\%D0\%B0\%D1\%80\%D1\%96\%D0\%B0\%D0\%BD\%D1\%82.pdf (In Ukrainian)

Kozhemyakina, O. M. (2012). Arkhetypni zasady komunikatyvnykh praktyk manipulyuvannya doviroyu. Theory and Practice: Proceedings of the Association of Doctors of Science in Public Administration: Special Issue. Kharkiv, pp. 263-272. (In Ukrainian)

Kravchenko, A. A. (2013). Arkhetyp uchytelya: ideya, obraz, vidpovidalnist. Lviv: Liga Press, 421 p. (In Ukrainian)

Los, Julia (2019). How to use the archetype method in branding. Retrieved from https://yulialos.com/archetypes/kak-ispolzovat/ (In Russian)

Mark, M. and Pearson, K. (2005). Geroy $i$ buntar [Hero and Rebel]. St. Petersburg: Peter, 336 p. (In Russian)

Medinska, Julia (2004). Kolektyvne nesvidome yak hlybynna determinanta etnichnoho mentalitetu. Psychology and society. 2: 50-117. (In Ukrainian)

Nekita, A. G. (2001). Mechanisms of unconscious social distortion of the archetype phenomenology. (Candidat's thesis, Absrtact). Skovoroda Institute of Philosophy of NAS Ukraine. Kyiv, 16 p. (In Ukrainian) 
Nikolova, O. (2014). Providni oriyentyry porivnyalnykh studiy typolohiyi psevdomorfnykh personazhiv. Humanities education in technical higher education institutions. 30: 178-193. (In Ukrainian)

Polikanova, A. V. (2012). Vykorystannya teoriyi arkhetypiv u praktytsi brendynhu. Retrieved from https://clck.ru/MBNMG (In Ukrainian)

Publichnoye upravleniye: teoriya i praktika (2010). Collection of scientific works of the Association of Doctors of Sciences on Public Administration, 3-4. Kharkiv, 432 p. (In Russian)

Radchenko, O. and Kriukov, O. (2014). Derzhavna molodizhna polityka: osnovni ponyattya ta pryntsypy yak arkhetypy formuvannya ta realizatsiyi v publichnomu prostori. Public administration: theory and practice: 142-147 (In Ukrainian).

Romankova, L. M. (2015). Tsinnisno-smyslova determinatsiya v osvitniomu prostori vyshchoho navchalnoho zakladu. Nova paradyhma, 108: 193-202. (In Ukrainian)

Severynova, M. (2012). Arkhetypovi obrazy sakralnoho na prykladi kontsertu №3 dlya fortepiano, strunnoho orkestru ta velykoho barabana M. Skoryka. Kultura Ukrayiny, 39: 12-22. (In Ukrainian)

Sohan, L. V. (2019). Review of the monograph by E.Afonin and A.Martinov "The Ukrainian Miracle: From Depression to Social Optimism". Retrieved from http://publish-ukma.kiev.ua/ua/ recenziyi/68-recenziya-na-monografiyu-afonina.html

Sushyy, Olena (2013). Sotsialnyy dialoh u fokusi arkhetypnoyi paradyhmy. Public Management: Theory and Practice: 252-256. (In Ukrainian)

Tikhovska, O. (2015). Personifikatsiya arkhetypu Tini u mifolohichnomu svitohlyadi ukrayintsiv. Modern Problems of Linguistics and Literary Studies: Issue 20: 130-135. (In Ukrainian)

Uris, T. (2016). Arkhetyp yak estetychna dominanta khudozhnioho vyrazhennya modusu natsionalnoyi identychnosti v suchasniy ukrayinskiy poeziyi. Uzhgorod University Scientific Bulletin. Series: Philology. 1: 96-100. (In Ukrainian)

Yung, K.-G. (1996). Dusha i mif: shest arkhetipov [Soul and Myth: Six Archetypes]. Kyiv: State Book of Literature for Adolescence, 384 p. (In Russian)

Zakrevsky, V. E. (2002). The Artetype of the Perfect Man as a Phenomenon of Public Consciousness. (Candidat's thesis, Absrtact). Ushinsky South Ukrainian State pedagogical university. Odessa, 19 p. (In Ukrainian)

\section{LIST OF REFERENCES LINKS}

Арпентьева М. Р., Брайцева С. В. Архетипы и ролевые модели в визуальном брендинге. Знак: проблемное поле медиаобразования. 2018. №2 (28). URL: https://cyberleninka.ru/ article/n/arhetipy-i-rolevye-modeli-v-vizualnom-brendinge (Дата звернення: 26.12.2019).

Афонін Е., Мартинов А. Архетип і соцієтальне: взаємодія і взаємовпливи. Публічне управління: теорія та практика. 2013. Спец. вип. С. 193-200.

Архетипіка і державне управління: громадянська самоорганізація, соціальна мобільність, суспільна інтеграція: зб. наук. пр. переможців і кращих авторів Третього міжнар. конкурсу молодих учених; 30 квітня 2015 р., Ужгород - Скаліца / за наук. ред. Е. А. Афоніна, Г. Л. Рябцева. Київ: Псіхея, 2015. $84 \mathrm{c}$.

Бєлєхова Л. І. Архетип, архетипний смисл, архетипний образ у лінгвокогнітивному висвітленні (на матеріалі віршованих текстів американської поезії). Науковий вісник Дрогобицького державного педагогічного університету імені Івана Франка. Сер.: Філологічні науки (мовознавство). 2015. № 3. C. 6-16.

Бутиріна М. В. До питання застосування архетипів у комунікаційній практиці. Вісник Дніпропетровського універсиmemy. Серія "Соціальні комунікації. 2013. Вип. 13. С.13-17.
Демчук Р. В. Міфопоетика як засіб моделювання української ідентичності: культурно-цивілізаційний контекст: автореф. дис. ... д-ра культурології: 26.00.01 / Нац. муз. акад. України ім. П. І. Чайковського. Київ, 2018. 34 с.

Донченко Олена, Романенко Юрій. Архетипи соціального життя і політика (Глибинні регулятиви психополітичного повсякдення). Київ: Либідь, 2001. 334 с.

Донченко О. А. Архетиповий менеджмент: монографія. Кіровоград, Імекс-ЛтД, 2012. 264 с.

Дубніченко В. Ю. Специфіка відображення православного архетипу у російській метафізичній традиції: автореф. дис... канд. фрілос. наук: 09.00.03 / Донецький національний університет. Донецьк, 2005. 20 с.

Закревський В. Е. Артетип досконалої людини як феномен суспільної свідомості: автореф. дис. канд. фрілос. наук: 09.00.03/ Південноукраїнський держ. педагогічний ун-т ім. К. Д. Ушинського. Одеса, 2002. 19 с.

Марк М., Пирсон К. Герой и бунтарь. Санкт-Петеребург: Питер, 2005. 336 с.

Казимирів Х. Архетип, концепт і міфологема в системі музичних категорій. Вісник Прикарпатського університету: мистецтвознавство. 2013. Вип. 28-29, ч 1. С. 190-195.

Ковальчук Н. Д. Символічні структури етнокультурного процесу в Україні: дис... д-ра фрілос. наук: 09.00.04 / Інститут філософії ім. Г. С. Сковороди НАН України. К., 2007. 404 с.

Ковтун Н. М. Архетип як інваріантна форма духовного життя. Матеріали науково-методичного семінару. 2009. URL: http://eprints.zu.edu.ua/6256/1/\%D0\%9A\%D0\%BE\%D0\%B2\%D1\%82\%D1\%83\%D0\%BD\%20\%D0\%9D\%20\%D0\%B0\%D1\%80\%D1\%85\%D0\%B5\%D1\%82\%D0\%B8\%D0\%BF\%20\%D1\%96\%D0\%BD \%D0\%B2\%D0\%B0\%D1\%80\%D1\%96\%D0\%B0\%D0\%BD\%D1\%82.pdf

Кожем'якіна О. М. Архетипні засади комунікативних практик маніпулювання довірою. Публічне управління: теорія та практика: збірник наукових праць Асоціації докторів наук 3 державного управління: Спеціальний випуск. Харків: Вид-во "ДокНаукДержУпр", 2012. С. 263-272.

Кравченко А. А. Архетип учителя: ідея, образ, відповідальність. Львів: Вид-во "Ліга-Прес", 2013. 421 с.

Лос Юлия. Как использовать метод архетипов в брендинге. URL: https://yulialos.com/archetypes/kak-ispolzovat/

Мединська Юлія. Колективне несвідоме як глибинна детермінанта етнічного менталітету. Психологія і суспільство. 2004. № 2. C. 50-117.

Некита А. Г. Механізми несвідомого соціального спотворення феноменології архетипу: автореф. дис. ... канд. філос. наук: 09.00.03 / Ін-т фрілос. ім. Г. С. Сковороди НАН України. К., 2001. 16 c.

Ніколова О. Провідні орієнтири порівняльних студій типології псевдоморфних персонажів. Гуманітарна освіта в технічних вищих навчальних закладах. 2014. № 30. С. 178-193.

Поліканова А. В. Використання теорії архетипів у практиці брендингу. 2012. URL: http://repository.hneu.edu.ua/bitstream/ 123456789/385/1/\%D0\%9F\%.pdf

Публичное управление: теория и практика: сборник научных работ Ассоциации докторов наук государственного управления. Харьков: Изд-во "ДокНаукДержУпр", 2010. № 34. 432 c.

Радченко О., Крюков О. Державна молодіжна політика: основні поняття та принципи як архетипи формування та реалізації в публічному просторі. Публічне управління: теорія та практика. 2014. С. 142-147.

Романкова Л. М. Ціннісно-смислова детермінація в освітньому просторі вищого навчального закладу. Нова парадигма. 2015. Вип. 108. С. 193-202.

Северинова М. Архетипові образи сакрального на при- 
кладі концерту №3 для фортепіано, струнного оркестру та великого барабана М. Скорика. Культура України. Вип. 39. 2012. C. $12-22$.

Сохань Л. В. Рецензія на монографію Е.Афоніна і А.Мартинова "Українське диво: від депресії до соціального оптимізмy". URL: http://publish-ukma.kiev.ua/ua/recenziyi/68-recenziyana-monografiyu-afonina.html

Суший Олена. Соціальний діалог у фокусі архетипної парадигми. Публічне управління: теорія та практика. 2013. C. $252-256$

Тиховська О. Персоніфрікація архетипу Тіні у міфологічно- му світогляді українців. Сучасні проблеми мовознавства та літературознавства: зб. наук. праць. Ужгород, 2015. Вип. 20. C. $130-135$.

Урись Т. Архетип як естетична домінанта художнього вираження модусу національної ідентичності в сучасній українській поезії. Науковий вісник Ужгородського університету. Серія: Філологія. 2016. Вип. 1. С. 96-100.

Берн Э. Игры, в которые играют люди; пер. с англ. Nykӧping (Sweden): Philosophical arkiv, 2016. $164 \mathrm{c.}$

Юнг К.-Г. Душа и мифр: шесть архетипов; пер. с англ. Киев: Гос. б-ка литературы для юношества, 1996. 384 с.

Алла Макарова,

Житомирський державний університет (м. Житомир, Украӥна)

e-mail: Makarova_AO@ukr.net, ORCID 0000-0001-7270-0135

\section{АРХЕТИПОВИЙ ПІДХІДДО ДІЯЛЬНОСТІ: ЛЕГІТИМАЦІЯ ПРАКТИКОЮ}

Сучасна реальність потребує імплементації у практику, ствердження як програми практичної діяльності нових розроблених теоретично підходів, серед яких архетиповий підхід видається одним із найбільш перспективних, оскільки враховує реальні мотиви діячів як суб'єктів. У статті висвітлено особливості архетипового підходу до діяльності в окремих сферах суспільної практики з точки зору реалізації в повсякденному житті, а не лише в теорії. Розглядаються приклади застосування архетипового підходу в практиці маркетингу, зокрема, брендингу, у педагогічній практиці та практиці політичної дипломатії. Наголошується на важливості врахування архетипової схильності об'єктів впливу в цих сферах та побудови адекватної їм схеми діяльності в тому числі на цих засадах. Наводиться розгорнутий перелік окремих архетипових класифікацій, диференціюються архетипи та ролі. В якості методологічної бази використано модель дванадцяти архетипів М. Марк и К. С. Пірсон, серед яких акцентовано типи "Простодушний", "Славний малий", "Дбайливий", "Творець", "Мудрець", "Шукач", "Бунтар", "Блазень", "Герой", "Маг", "Правитель". Окреслено різницю між змістом світогляду цих архетипів на прикладі їх актуальної або потенційної легітимації у практиці брендингу, педагогіки та дипломатії. Автор звертається до українських реалій, зокрема, проводить архетиповий аналіз дипломатичних переговорів між керівництвом Росії та глав європейських держав 3 приводу припинення війни на сході України. Запропоновано власну оцінку причин неефективності таких переговорів з точки зору архетипового підходу. Наведено огляд доробків сучасних українських учених у напрямку легітимації архетипового підходу в різних сферах практики.

Ключові слова: архетип; архетиповий підхід; діяльність; брендинг; роль; педагогіка; дипломатія.

(C) Alla Makarova

Надійшла до редакції: 06.01.2020

Прийнята до друку: 24.01.2020 